\title{
Insect frass in Baltic amber
}

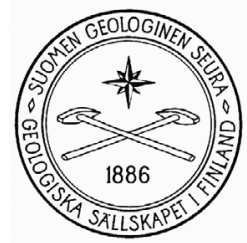

\author{
Matti Nuorteva ${ }^{1)}$ and Kari A. Kinnunen ${ }^{2) *}$ \\ 1) Alkutie 28 D, FI-00660 Helsinki, Finland \\ 2) Geological Survey of Finland, P.O. Box 96, FI-02151 Espoo, Finland
}

\begin{abstract}
Inclusions of wood debris loosened from pine-like trees are abundant in Baltic amber of Eocene and Oligocene age. The possibilities to find insect frass and excrement among wood debris are outlined and some examples are given. Comparison with the frass and excrement produced by present-day insects provide a possibility to identify insects even though their fossils are lacking. This information can be used to characterize former forest environments. Amber forests may have also covered Southern Finland, and this possibility is discussed. Furthermore, the presence of wood debris may be utilized to recognize amber fakes, which is important for both gem trade and paleontology. It is proposed that databases and identification keys of frass and excrement should be constructed.
\end{abstract}

Keywords: amber, fossils, inclusions, Insecta, wood, fecal pellets, identification, Poland, Lithuania

*Corresponding author e-mail: kari.kinnunen@gtk.fi

\section{Introduction}

The largest known deposits of fossil tree resin, amber, are located along the southern coasts of the Baltic region. It is known as Baltic amber as a gemstone and in the geological literature. Baltic amber was formed as a resin during the Eocene epoch about $30-50 \mathrm{Ma}$ ago (Ander, 1942; Krzemińska \& Krzemiński, 1992; Grimaldi, 1996; Ross, 1998). Large amounts of resin were preserved after it amberized into hard fragments, and when it was repeatedly transported into new sedimentary environments. The original location of the amber trees, however, has not been preserved in the geological record. The environment of the amber forests can only be approximated on the basis of the plant and animal remains preserved in it.

It is not known for certain, which tree or trees were the resin-segregating ones. It may have been
Pinites succinifer (Goeppert \& Berendt, 1945) Conwents pine or pines. It resembled present-day pines like Pinus silvestris L. species. Morphological findings and pollen data both point to the family Pinaceae (Weitschat \& Wichard, 1998). However, Zherikhin (2002) notes that many species currently living on pines have not been identified in Baltic amber. Moreover, the chemical composition of the resin indicates Agathis (Araucariaceae) and Cedrus trees (Poinar, 1992; Krumbiegel \& Krumbiegel, 2005) or genus Pseudolarix (Grimaldi, 1996; Grimaldi \& Engel, 2005).

Beck (1993) has comprehensively studied the chemical composition of Baltic amber, and concludes that it relatively closely resembles the resin of modern Agathis species. According to Beck (1993), the wood 
anatomy of the Araucariaceae, which was only recently divided from the Pinaceae family, is rather similar to that of Agathis. These trees are nowadays extinct, and the chemical composition of their resin is close to that of modern East-Asian species. Some insects living in trees are especially faithful in selecting their host trees. When more amber insects have been studied this will provide new information on the distinctiveness of these ancient trees.

The large amount of amber preserved to the present day shows that the resin flow was intense, which may indicate disturbances in the life cycle of the trees. However, the causes that led to these disturbances are unknown. One can speculate on climatological causes or on injuries caused by insects or pathogens.

When the composition of this entomofauna is resolved, it will be possible to understand the circumstances that contributed to the destruction of amber pines. Several studies, e.g. Ander (1942), Bachofen-Echt (1949), Larsson (1978), Poinar (1992), Krzemińska \& Krzemiński (1992), Weitschat \& Wichard (1998) and Zherikhin (2002), have focused on the entomofauna together with the amber data. However, knowledge of the actual species that caused the damage, is still inadequate.

There is no information available on specific pathogenic insects that could have been disastrous to trees. The data on present-day insects which damage forests, imply that their activities may have led to the death of amber trees. When speculating on the causes of the resin flow in damaged trees, however, one should remember that the largest destructive insects were not trapped in the resin, because insects larger than $1 \mathrm{~cm}$ are rare in amber (Schlee, 1990; Krzemińska \& Krzemiński, 1992; Poinar, 1992). Perhaps large, powerful insects did not stick to the resin, or perhaps birds and other predators ate them. Similarly, complete spider fossils are usually below $1 \mathrm{~cm}$ (Wunderlich, 1986).

The living styles of present-day insects on pines (Pinus) are reasonably well known. This insect fauna is relatively similar to those present in the Eocene and Oligocene. The evolution of insects and their parent trees has probably been synchronous for millions of years (Krzemińska \& Krzemiński, 1992). In Baltic amber, practically all the insects correspond to existing families, about half to existing genera, and a few close to still existing species (Larsson 1978, Poinar 1992). However, Wunderlich (1986) estimates that $75 \%$ of the spider fauna in Baltic amber consists of extinct genera. The estimate from his latest studies (Wunderlich, 2004) on the fauna in Samland amber is $88 \%$.

The insect finds show that the insect fauna of the ancient amber pines resembled that of present pines (Larsson 1978). Only the largest species are lacking from amber. No fossils have been found in Baltic amber that could represent needle-eating sawflies ( $\mathrm{Hy}$ menoptera: Pamhilididae, Diprionidae) or moths (Lepidoptera: Geometridae, Lymantriidae, Noctuidae, Lasiocampidae, Thaumatopoeidae, Sphingidae). However, their larvae probably lived in the tree crowns. Only two fossil species of Diprionidae sawflies have been described (Bachofen-Echt, 1949). The species that belonged to the above-mentioned orders of insects and which consumed needles in the canopies, may have reduced the vitality of the trees.

Surprisingly few descriptions exist on the particularly species-rich family of beetles, and of flat-headed borers (Buprestidae) only about ten species (Spahr, 1981; Zherikhin, 2002). Similarly, large long horned beetles (Cerambycidae) have only seldom been adhered in resin, except for some of their small larvae (Larsson 1978). Thus only about twenty families have been published (Spahr, 1981; Poinar, 1992). Impressive individuals belonging to these two families may attract forgers, and erroneous records are likely.

Nowadays the bark beetles (Scolytidae) are significant destroyers of trees. Many families and species of bark beetles have been observed in Baltic amber (Spahr, 1981; Keilbach, 1982). On the other hand, the number of individuals is small, although these insects may attack dying trees and therefore they should be more frequent (Schedl, 1947, 1967; Bachofen-Echt, 1949; Larsson, 1978; Krzemińska \& Krzemiński, 1992). Those species which nowadays attack relatively healthy trees are not known in amber. The trees in amber forests may have developed 
resistance against predators widespread in recent trees (Zherikhin, 2002), or perhaps our knowledge of the insects in amber forests is still too deficient.

Moreover, insect predators and parasitoids provide some suggestions on their host animals, although their host insects are absent as fossils. Although one cannot find the bodies of the insects themselves, it is possible to obtain information on the presence of pests by identifying their waste, excrement and frass. While eating, however, these former destructive insects would have produced plenty of excrementd and wood dust. These particles probable adhered to the resin. Different pest genera and species have distinct waste products, which can be morphologically identified. For example, Eckstein (1939), Nolte (1939) and Becker (1949) have described how to identify conifer-eating insects on the basis of their frass.

The waste products of insects in amber have not aroused much research interest (Weidner, 1956; Zherikhin, 2003). Only Weidner (1956) has described termite excrement in Baltic amber. In addition, Grimaldi \& Engel (2005) have published one photo depicting mineralized excrement of a termite from Eocene age wood in Queensland, Australia. Frass and fecal pellets have been found in Dominicean amber (Grimaldi, 1996). Wunderlich (2004) has described dissected remains of preys proced by spiders in Baltic amber. Arillo (2007) has recently reviewed studies, which depict insects paleobehaviours. Arillo (2007) suggests that defecation may result while insects are struggling against the sticky resin. However, morphologically distinctive excrement and frass are abundant and visible in many pieces of amber (Schubert, 1939; Schlee, 1990; Ross, 1998; Pielińska, 2001; photo of a piece of excrement in Dahlström \& Brost, 1995). By studying and comparing them with recent examples, it should be possible to infer the former presence of some insect genera.

This study is focused on the possibilities of identifying from Baltic amber wood particles and excrement produced by insects. The study is based on the characteristics of some modern debris and on comparison with similar finds in Baltic amber.

\section{Baltic amber forests}

In order to better understand the insect fauna of pinelike amber forests, it is important to collate the published facts on these forests, their locality, vegetation, climate and composition of the insect fauna.

\section{I. Provenance of Baltic amber}

Besides the Baltic countries, Baltic amber is also found in England, Denmark, Germany and Russia up to the Ural Mountains. According to Bachofen-Echt (1949), the amber-producing forests were located in Fennoscandia. It is generally believed, that amber was formed in Central Scandinavia, Finland, Estonia, and partly in Russia (Ander, 1942; Kremińska \& Kremiński, 1992; Grozonkowski, 2004; Selden \& Nudds, 2004; Krumbiegel \& Krumbiegel, 2005). The known deposits of Baltic amber are all secondary and have been transported by glaciers, rivers and littoral processes. The low specific gravity $(1.05-1.09)$ and therefore the buoyancy of amber enabled it to easily drift especially in saline seawater (1.03) over very long distances.

It is now known that from the late Oligocene to the early Miocene (see Overeem et al., 2001) the Eridanos fluvio-deltaic system transported pieces of amber from northern Fennoscandia to the Gdansk delta (Krumbiegel \& Krumbiegel, 2005). This river system occupied the area of the present Baltic Sea and, in its later stage, reached as far as the North Sea (Fig. 1). In the Holocene, storms redistributed pieces of amber from the sediments in Poland and Kaliningrad to the west and east along the shoreline of the southern Baltic (e.g. Reinicke, 1995; Botheroyd \& Botheroyd, 2004; Wichard \& Weitschat, 2005). The Eridanos River flowed from the Gulf of Bothnia along the Baltic basin to the Gdansk delta. These ancient river channels were leveled down during subsequent glacial activity. The Eridanos system was huge and comparable in size to the present Orinoco delta in southern America.

The huge Gdansk delta and the amber occurrences in Samland (now in the Kaliningrad area) are the areas from where our research material originates. 


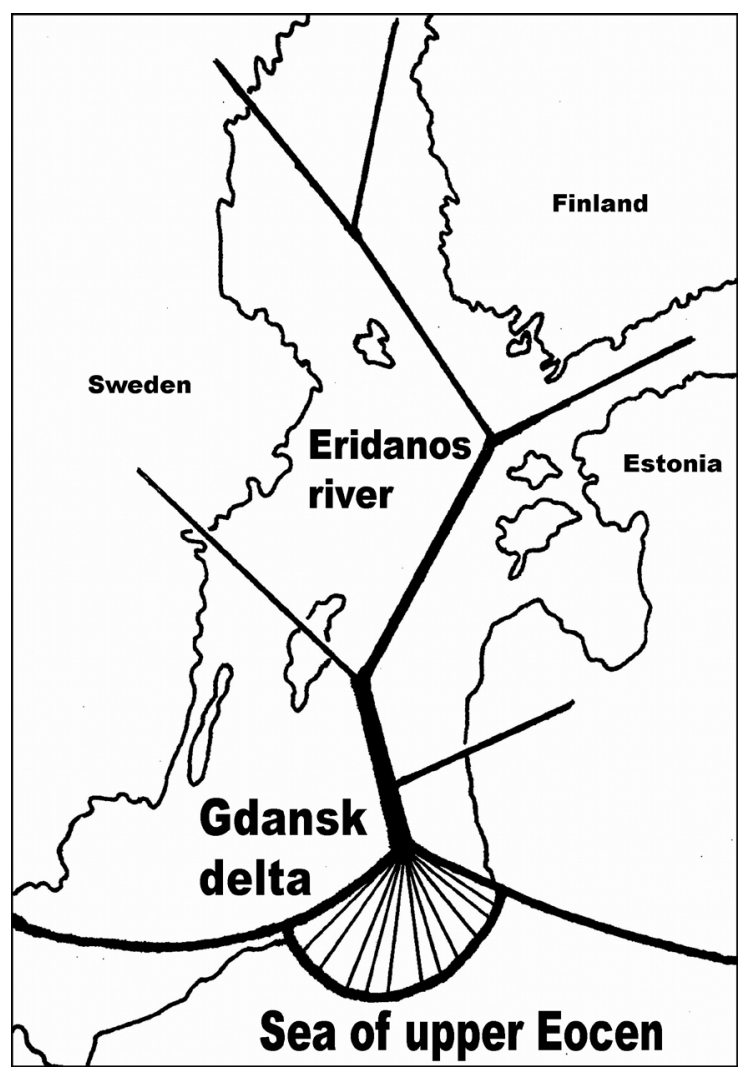

Fig. I. Eridanos fluvio-deltaic river system (Amber river) of the Cenozoic age and its Gdansk delta along the contemporary coastline. The main commercial amber deposits were originally located in these deltaic sediments and later redeposited to the glacial sediments. The amber material of the present study was mainly from this delta area. The ancient amber forests were located in this river area mainly in southern and central Fennoscandia. Compiled from Overeem et al. (200I), Botheroyd \& Botheroyd (2004) and Kosmowska-Ceranowicz (2004).

\subsection{Climate}

At the end of the Cretaceous the Baltic region was positioned about $10^{\circ}-12^{\circ}$ further south than its present position (Larsson, 1978). At that time, the climate in the Baltic region was predominantly subtropical. It is possible that the differences in temperature along the north-south axis were smaller than today, and thus tropical and subtropical life forms had a more extensive distribution (Weitschat $\&$ Wichard, 1998; Grimaldi \& Engel, 2005). Thermophilic species were common in amber forests, but in the end of
Eocene the climate cooled down. This led to changes in fauna and flora (Weitschat \& Wichard, 1998; Wichard \& Weitschat, 2005).

\subsection{Vegetation}

Recognizable plant fossils are much rarer in amber than insect finds. As a result, information about the vegetation is more deficient, although the living habits of the fossilized insects may indicate the former presence of certain plant species. It is important to know the abundance of tree species in amber forests (Ander, 1942; Bachofen-Echt, 1949; Larsson, 1978; Krzemińska \& Krzemiński, 1992; Grimaldi, 1996; Weitshat \& Wichard, 1998; Kosmowska-Ceranowicts, 2001; Krumbiegl \& Krumbiegl, 2005; Wichard \& Weitschat, 2005). In addition to pine-like trees, other conifers were also present. There were numerous species of oak especially among the deciduous trees.

Tiny hairs on the leaves and buds of oaks are typical of Baltic amber (Bachofen-Echt, 1949; Krzemińska \& Krzemiński, 1992; Wichard \& Weitschat, 2005). Some species, for example various palm trees as well as Castanea and Mangolia, which are more southerly today, were present in amber forests. Today, similar forests primarily grow in North America and in Palearctic China (Ander, 1942). No forests that are completely identical with the ancient amber forests are known anywhere.

Plant and animal remains in Baltic amber indicate that pine-like amber trees grew in or near aquatic environments. The abundance of water bug fossils in amber clearly verifies this (Wichard \& Weischat, 1996). The resin of pine-like trees growing in mires was preserved in moist sediments, where it was not oxidized. The aquatic environment has likewise protected the amber pieces against the action of forest fires. Several species of coniferous tree most likely grew on drier land too, but their resin was oxidized and destroyed (Weischat \& Wichard, 1998). It should be noted that the Trichoptera and Diptera fauna found in amber consist of species living in flowing as well as in standing water. This suggests that the 
amber forests grew in a mountaneous landscape (Ander, 1942; Bachofen-Echt, 1949; Weitschat \& Wichard, 1998).

\subsection{Insects}

The abundant, well-preserved insect inclusions make it possible to compare them with present-day insects. The fauna which was specifically associated with the living amber trees at that time has since disappeared and, according to Larsson (1978), on the whole its genera are only distantly related to present forms. The insect fauna differs from the European one, although there are some similarities. Tropical insects can exist together with holoarctic fauna, although the subtropical component is usually the dominant one (Ander, 1942; Larsson, 1978; Poinar, 1992; Szadziewski $\&$ Sontag, 2001). When one compares the insects in amber to present insects and their known living habits, it is clear that there are similarities between the living habits.

Insect fauna associated with resin-excreting trees is obviously the most numerous. The insects were trapped in resin while it was still fluid, and hence night-active and hibernal-active insects are rare as fossils (Krzemińska \& Krzemiński, 1992). It is not known whether some of the species known as fossils from Baltic amber are still living. However, all the orders and main part of the families and genus are still known today, although some of them are presently living outside Europe. The cooling of the climate presumably made some insects to move south into warmer conditions (Poinar, 1992; Wichard \& Weitschat, 2005). Near relatives of some insects, now extinct in Baltic countries, live for example in Spain, northern and southern America, South Africa, Southeast Asia, and Australia (Ander, 1942; Larsson, 1978; Krzemińska \& Krzemiński, 1992; Grimaldi, 1996; Weitschat \& Wichard, 1998; Ross 1998).

\section{Material and methods}

Large quantities of Baltic amber of varying quality from Poland, Lithuania and Kaliningrad appeared on the western market in the 1990's. At that time, one of us (K.K.) had the opportunity to examine large amber parcels for inclusions. He bought pieces of amber with interesting inclusions for his private collection. This private collection (K.K.) consists of 1085 amber pieces with a diameter ranging from 1 to 8 $\mathrm{cm}(21$ amber pieces are in the size range $4-8 \mathrm{~cm})$. Altogether 43 doubly polished slabs have been prepared from selected samples for microscope examination and photographic documentation. In these samples insects were rare (only a few percent of the samples contained them), but wood debris was surprisingly common (Figs. 2 and 5). Wood fragments were visible in most lower grade, but otherwise transparent amber pieces, most of which originated from the Gdansk area.

Some of these microscopic wood fragments resembled debris produced by certain wood boring insects (noticed by K.K. in the beginning of the 1990's). Their geometrical shape resembled the sawdust produced during the carving or drilling of wood material. The amber containing these inclusions were shown to the other author (M.N.), who is a professor of forest entomology. M.N. became keenly interested in the topic. His expertise in insect habitats in trees (e.g. Nuorteva, 1956), subfossils (Koponen \& Nuorteva, 1973) and excrement (Nuorteva, 1972) and in the identification of wood markings, was fundamental to this study.

The amber specimens were first studied under a stereomicroscope and morphologically classified. Some surfaces were oiled in order to obtain a sharp view of the the inclusions. Tens of sections enclosing wood fragments were prepared from pieces of amber. These sections were polished on both sides. The thickness of the sections was approximately $3 \mathrm{~mm}$. They were studied under a stereomicroscope, polarizing microscope and then photographed. Our amber material mainly consisted of pieces from 1 to $3 \mathrm{~cm}$ in size. Only 21 larger specimens were studied. The size range is close to the typical size of amber in Holocene sediments.

Our research material mainly consisted of commercial pieces of Baltic amber obtained from Poland 


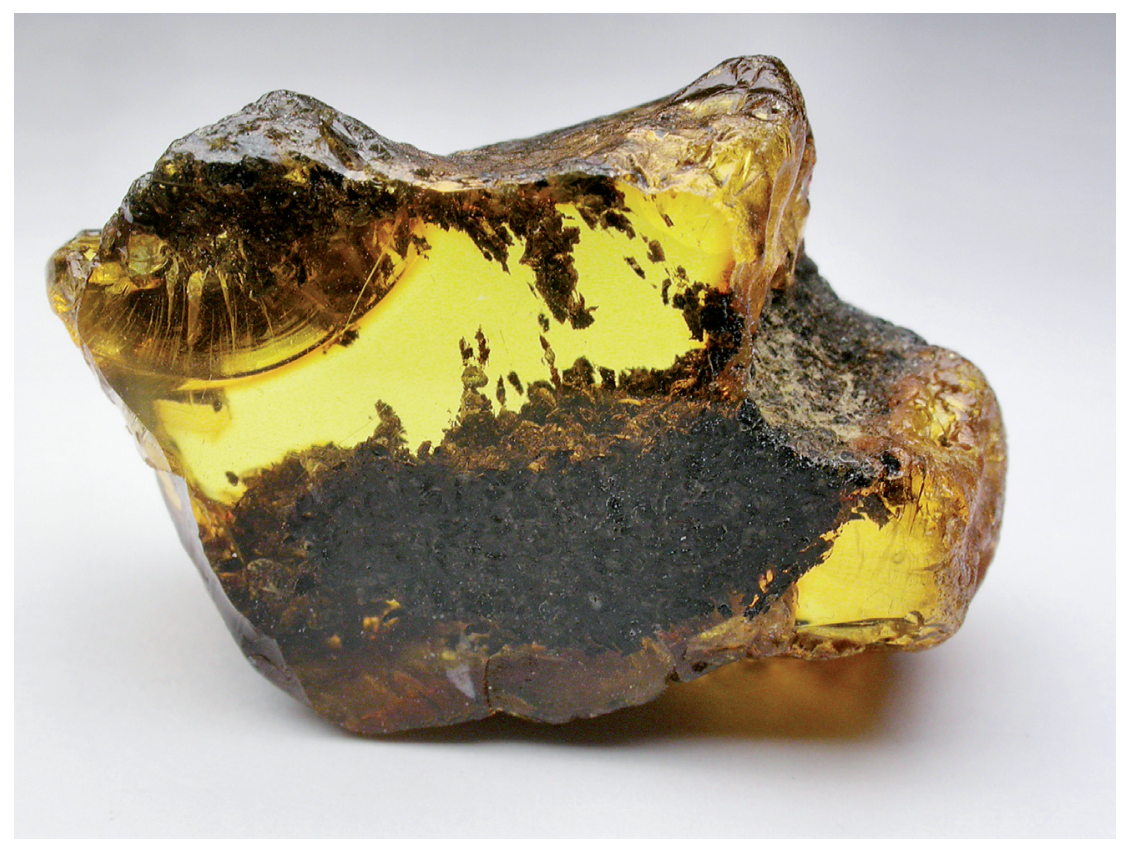

Fig. 2. Dark layer of wood debris in Baltic amber, most probably from Gdansk area, Poland. Length $32 \mathrm{~mm}$. In private collection (K.K.). Photo: K.K.

and Lithuania. Most of them most probably originate from Jantarnyi, Kaliningrad. In addition, 26 pieces of amber from the paleontological collections in Geological Museum of Finnish Museum of Natural History, University of Helsinki, were studied. Their locality was given as Samland. The 170 pieces of Baltic amber from the entomological collection in Zoological Museum of Finnish Museum of Natural History, University of Helsinki, the precise origin of which was not known, were also studied. Additionally, 34 amber pieces purchased by M.N. were included in the study.

The museum ambers in Geological Museum were commonly hydrated and covered with a network of microfractures (cf. Shashoua, 2002). Microscopic study of these damaged pieces was problematic. The samples were coated with castor oil in order to obtain photographs. The museum personnel granted permission for this procedure, because no damage was caused to the specimens.

The exact locality of most of our amber specimens from the Baltic area was unknown. We think, however, that this has not had any significant influence on our conclusions. Amber pieces have been repeatedly redeposited throughout their geological history. The exact localities - if known - would only provide information about these redeposition processes, and not about the primary habitat of amber forests.

\section{Genuineness of the amber}

Amber fakes are problematic and sometimes difficult to recognize and pose a serious problem in research and trade. Forgers are not interested in small pieces of minor value. However, gem-grade and museumquality pieces are more problematic, and we also examined a number of them in our study. As pieces of fake amber with large insect inclusions are common on the market, methods for validating their authenticity are important.

The inclusion of fossils, insects or other, which is extinct today, would definitely prove the authenticity. However, most insects can only be determined to the genera level, and this is therefore of limited use in this connection. Likewise, most insect fossils are deformed and incomplete making their identification difficult. For this reason, we have used other methods.

Inclusions of wood debris are characteristic of $\mathrm{Bal}-$ tic amber and they provide a simple way to test the genuineness of specimens. We would like to add wood fragments to the list of inclusions, together with pyrite grains and tiny hairs probably detached from the 


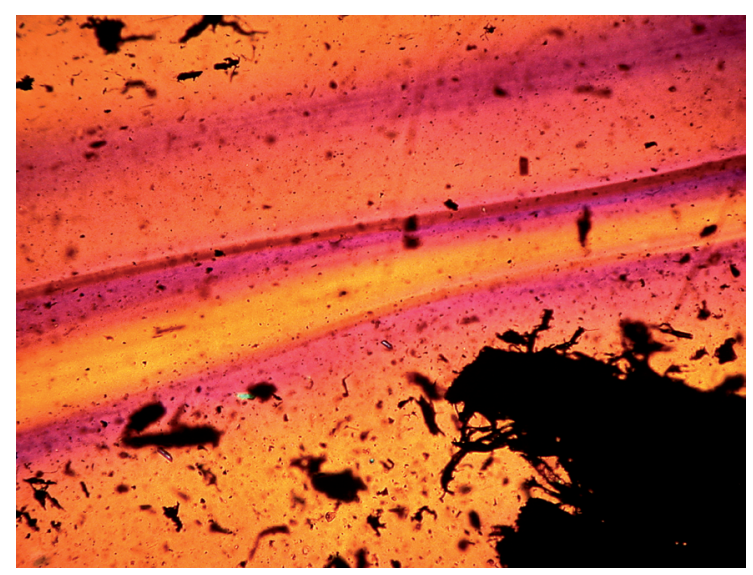

Fig. 3. Stress anisotropism between amber layers. Dark particles are composed of wood debris. Double polished section of Baltic amber. In private collection (K.K.). Width of the picture area is $4 \mathrm{~mm}$. Transmitted crossed polarized light with lambda-plate. Photo: K.K.

male flowers of oak trees (see Bachofen-Echt, 1949; Ross, 1998), that are considered as diagnostic of genuine Baltic amber. In addition, the wave-like layering of the amber (Fig. 3), which is intimately connected to the inclusions and described in detail in the following, seems to be an important diagnostic tool.

Other amber tests have also been proposed. They include differences in fluorescence under ultraviolet radiation and the absence of stress-induced polarization figures around the inclusions. We tried these tests but, in our opinion, they did not give reliable answers about amber authenticity.

\section{Amber in Finland}

To our knowledge, amber has not been found in situ in Finland; although amber forests most probably grew in the area of present southern and central Finland (see Ander, 1942; Bachofen-Echt, 1949; Katinas, 1983; Kosmowska-Ceranowicz, 2004; Wichard \& Weitschat, 2005).

There are three records of amber finds in Finland: at Ingarskila in Inkoo (Holmberg, 1857), and at Nauvo and at Borstö in Airisto (Laitakari, 1967). According to a number of Finnish archaeologists, the amber from Ingarskila most probably represent stone age imports from southern Baltic areas. The finds in Nauvo and Borstö were pebbles found on the shore of Airisto Island. They were described in 1700's in the records of Turku University. These samples were most probably destroyed in 1827 in the great fire of Turku. The amber pebbles may have been attached to algal drift and thereby transported from the south to their present location. Or they may have been transported in ballast material used in sailing ships for centuries. This interpretation is supported by the fact that Paleogene $(66-23 \mathrm{Ma})$ sedimentary rocks and strata are not known in Finland (cf. Kohonen \& Rämö 2005).

From the Comb Ceramic Stone Age (ca 5000 BC - 3200 BC) onwards, amber was imported into Finland mainly as finished products: pendants, beads and small sculptures. The finds are abundant, especially in the red-ochre tombs dated to the Comb Ceramic culture in southern and middle Finland (Äyräpää, 1945, 1960). Well-preserved small amber objects with human forms have been found on the lake bottom in front of Astuvansalmi rock painting cliffs (Grönhagen, 1991). Uino (2005) has reviewed the Finnish literature on archaeological amber when describing the most recent archaeological finds of amber in Rävåsen, Ostrobothnia.

\section{Petrography of amber}

The morphology of pieces of amber may indicate their location and orientation in trees. This could narrow the potential insect candidates that produced the frass. Most lumps of amber are, however, rounded and fractured and their surface is weathered. This limits the possibility to interpret their original location in trees. Pieces of amber are easily transported in flowing water, because of their low density. Although in wet conditions they remain almost completely unweathered, the long drift distances have mechanically shaped their forms through abrasion. Most of our amber samples can be classified as superficial ambers formed outside the trunk. Slab-like, interior ambers formed in the trunk have only rarely been found. Most of our ambers in the superficial category resembled trunk amber with a very few drop-like ici- 
cle forms (see Katinas, 1983). The morphology of the side facing the trunk or twigs was typically better preserved and, in a few specimens, it still contained remnants of wood material.

We could not identify the species of wood fragments in our samples. Earlier published studies on ambers contained larger wood fragments. These fragments have been identified as pieces of Pinus succiniferum (see review in Gübelin, 1978).

The wood fragments in our samples showed a similar size range, regardless of the diameter of the host amber. Feret's diameter (the largest diameter present) was measured by image analysis using Image Tool software. The diameter of the wood fragments ranged from 0.6 $-1.8 \mathrm{~mm}$. The mean diameter was ca. $1 \mathrm{~mm}$.

In most cases the wood fragments were randomly scattered throughout the amber. In a few cases they were concentrated in layers, and in pile-like structures in the layers (Fig. 2). The base of the amber pieces (the surface facing the trunk) almost always contained more wood fragments.

On partly fractured pieces of amber, flow layers were visible as undulating, wave-like surfaces. Some pieces of amber were fractured along the contact surface between successive resin layers. In some of the polished amber sections, the contact surfaces were seen as bending lines in reflected light on their surface. In transmitted light the flow layers were observable when the doubly polished slab was swivelled to a position where the contact surfaces were aligned parallel to the microscope axis. Crossed polarized light showed that the contact surfaces of the flow layers were under minor stress (Fig. 3). In most cases their thickness varied within a few millimetres. In a few cases, however, it was possible to determine the top direction of the flow from deformed bubbles and ant inclusions located close to the contact surface. In general, the flow layers showed that the resin surfaces were convex upwards. This observation can be used in determining the original alignment of the lump of resin. The orientation of the wood fragments in the flow layers was mostly random. The viscosity of the resin probably prevented the flow from having an orientating effect.
The flow layer observations showed that the wood debris was specific to each resin layer. Some layers showed strong enrichments. A few pieces of amber had layers with wood fragments of different mean diameter. These findings may indicate that the wood debris was transported, together with the resin, to the site of solidification. Hair fibres detached from oak leaves may indicate eolian transport, because they were also found as inclusions, mainly in clear amber. However, wood fragments were rare in amber pieces containing oak leaf fibres.

The wood debris was also entirely embedded in individual resin layers, and not concentrated in the contact surfaces. The same applies to aerial contamination because bubbles were embedded in the individual flow layers. On the contrary, the infrequent insect inclusions were typically located on or near the contact surfaces.

\section{Possible frass producers}

\section{I. Needle eating insects}

Many larvae of butterfly species eat pine needles over large areas. The same applies to the larvae of some sawflies. Nolte (1939) has described the excrement produced by insects that eat pine needles. Using Nolte's procedure, Larsson \& Tenow (1980) measured the mass of the excrement and other waste fragments produced by some insect groups. The total amount of faeces produced was in the order of $11 \mathrm{~kg}$ dry weight/ha, and of green litter $1.5 \mathrm{~kg} / \mathrm{ha}$. This is a high figure compared to the small size of the particles. For this reason, we consider that they should also occur in amber. Some beetles (adults and larvae) also eat pine needles, but their excrement may be difficult to identify.

Aphides (Homoptera: Aphidoidea) that sucked tree sap from needles and branches are common in amber (Heie, 1967; Larsson, 1978; Zherikhin, 2002). When occurring in huge colonies, they may significantly reduce the vitality of trees. Aphids produce plenty of honeydew, which fall as small droplets from the crowns of deciduous and coniferous trees where they live. It is likely that traces of this sac- 
chariferous, sticky material may have been trapped in amber.

\subsection{Species living on tree bark}

Ants (Hymenoptera: Formicidae) exploit the honeydew of aphids. This may explain the commonness of ant fossils in amber. They also prey on small invertebrates. Their excrement is a fluid material.

Parasitical hymenoptera are likewise common in amber (cf. Larsson, 1978). Many are associated with specific host animals. Because recent examples are reasonably well known, it is possible to make conclusions about the host animals on the basis of the presence of specific parasites found in amber.

Likewise the prey of some coleoptera and their commensals living in the galleries of bark beetles has been preserved in amber (cf. Larsson, 1978).

Lycoriidae adults belonging to flies (the order Diptera) are common in amber (Ander, 1942; Evenhuis, 1994). Most of their larvae lived in humus material. Some larvae of the genus Sciara live as huge swarms on dying trees and eat their phloem. It is possible that the small, round excrement of these larvae could be found in Baltic amber.

Adults of dipterous flies of the Dolichopodidae family are abundant in Baltic amber (Larsson, 1978; Evenhuis, 1994). One genus (Medetera) of this family laid their eggs in the galleries of bark beetles, where the larvae operate as predators. However, they do not leave any recognizable excrement.

\subsection{Beetles penetrating under the bark}

The phloem layer below the bark is rich in nutrients and it attracts many beetles to breed. The adult bark beetles (Scolytidae) push dust when they drill through the bark and when they excavate egg galleries in the bark. This dust is fairly fine-grained, but its mass may be large. It is probable that some of them may have been included in amber. Thus, the characterization of wood dust may aid in verifying the former presence of bark beetles.
Some recent Denroctonus bark beetle species intrude into living trees and may create abundant flow of resin. Plenty of wood dust would adhere to the resin. Adult beetles know to avoid resin and thereby avoid becoming trapped. It is noteworthy that they have not been met in Baltic amber (Larsson, 1978). Wood dust mixed with amber should therefore be searched for. Members of this bark beetle, which live on Pinaceae conifers, existed already at the time when Baltic amber was formed. An engraving made by Denroctonus bark beetle has been identified on a petrified, middle Eocene (45 Ma) specimen of Larix altoborealis log from the Canadian High Arctic (Labandeira et al., 2001).

The frass of the larvae consists of fragments that became detached when the galleries were built and of excrement that passed through the alimentary canal. This larval frass usually remains below the bark and only drops out when the bark is splitting off. In such cases, the resin would most probably have already hardened and the adherence of frass particles would be only accidental. An exception to this is the present-day timberman (Acanthocinus aedilis L., Cerambycidae), which forms frass accumulations, in which the bark splits off while the tree still is relatively vital. This kind of debris could also be found in Baltic amber.

\subsection{Insects gnawing sapwood}

Many larvae of beetles groove their channels partly in the sapwood. Some larvae of the snout beetle (Pissodes, Curculionidae), and of other beetles, excavate a cavity or pit in the wood material when encapsulating, and then cover it with a wood splinter. Some larvae of Cerambycidae species (e.q. Acanthocinus aedilis L. and Rhagium inquisitor L.) may surround their pits with a crown like structure composed of wood splinters.

Some larvae dig their channels into the duramen (e.g. Monochanus). Abundant accumulations of frass may lead to bursting of the bark, and the frass is thereby expelled in late summer. Likewise, it is possible to find frass removed by beetle larvae in its sec- 
ondary environment. This may happen e.g. when moth larvae (Lepidoptera, Psychidae) attach wood frass to their cases while moving along the trunk (cf. the photos in Weitschat \& Wichard ,1998).

\subsection{Insects digging burrows in tree trunks}

Many genera of insects are known to bore their cavities in dead tree logs, but fluidal amber resin is no longer present in this stage. Their frass could be included only accidentally in amber. However, carpenter ants (Camponotus) do excavate their galleries in living trees. They do not eat the wood material, but instead push it out as frass. Adults of Camponotus have been found in Baltic amber (Keilbach, 1982).

Termites (the order Isoptera) are insects that live as colonies in subtropical and tropical areas. At the present time their most northern occurrences are in Central and Southern Europe. Some dig their nests in dead trees or those in a poor condition. Mostly they eat mushrooms that avoid direct sunlight. Termites may have been common in amber forests, but individuals from the swarms have mainly become adhered in the resin (Bachofen-Echt, 1949; Larsson, 1978; Poinar, 1992). The excrement of termites is easily identified and has been described from Baltic amber (Weidner, 1956). It should be noted, however, that termites are more frequent in Dominican than in Baltic amber (Schlee, 1990).

It is possible that resin may have dropped onto decayed wood material colonized by insects. This may also be one way in which frass has become included in amber. Typical fossils are the adult beetles of Anobiidae and Mordellidae, which produce a great deal of frass inside trees (Bachofen-Echt, 1949; Larsson, 1978).

\section{Frass produced by insects living on present-day pines}

Our examples of frass and excrement produced by insects are from Finland, because our aim here is only to demonstrate their diverse shape.
Literature on the frass and excrement produced by insects living in pines is scanty. Becker's (1949) study is the most detailed one. Some information can be found in Vité $(1952,1953)$ and Eckstein (1939), who also give data on other insects. Nolte (1939) describes excrement produced by insects living on the needles of firs and pines. Some information can be found on butterflies and sawflies in the literature. Brauns (1954) has described the excrement of larvae of Diptera.

In practice, only adult beetles and termites produce solid excrement. This is because the adults of most other species consume very little solid nutrition. The size of the excrement is similar, although there is variation in the size of the adults. On the other hand, the size of the excrement produced by larvae depends on their size. The difference in the size of excrement between adults and larvae require further study.

The size of the excrement depends on the growth stage of the larva. Identification of the small pieces of excrement produced by young larvae is usually impossible because one should know the largest excrement size of the individual species. Larvae eat in order to grow and therefore abundant excrement is produced. Food flow through the alimentary canal is rapid, and even the cell structure of the plant tissue they have eaten is usually still identifiable. A thin film (peritrophic membrane) usually envelops the excrement. The excrement produced by insects that eat wood material is always among the frass loosened from the wood material.

The shape of the excrement is often diagnostic. Some butterfly larvae, which eat pine needles, typically have longitudinal, transverse grooves on their excrement (Plate 1, B, see also Müller, 1992). Some hymenoptera larvae similarly eat pine needles. The excrement of Diprionidae pine sawflies are frequently in the form of parallelograms (Plate 1, A). They have been described in Nolte (1939), Eckstein (1939) and Escherich (1942).

Adult beetles and especially larvae do not eat all the wood and phloem particles they have detached from their galleries. The fragments loosened from the wood material are usually angular in shape, light-col- 

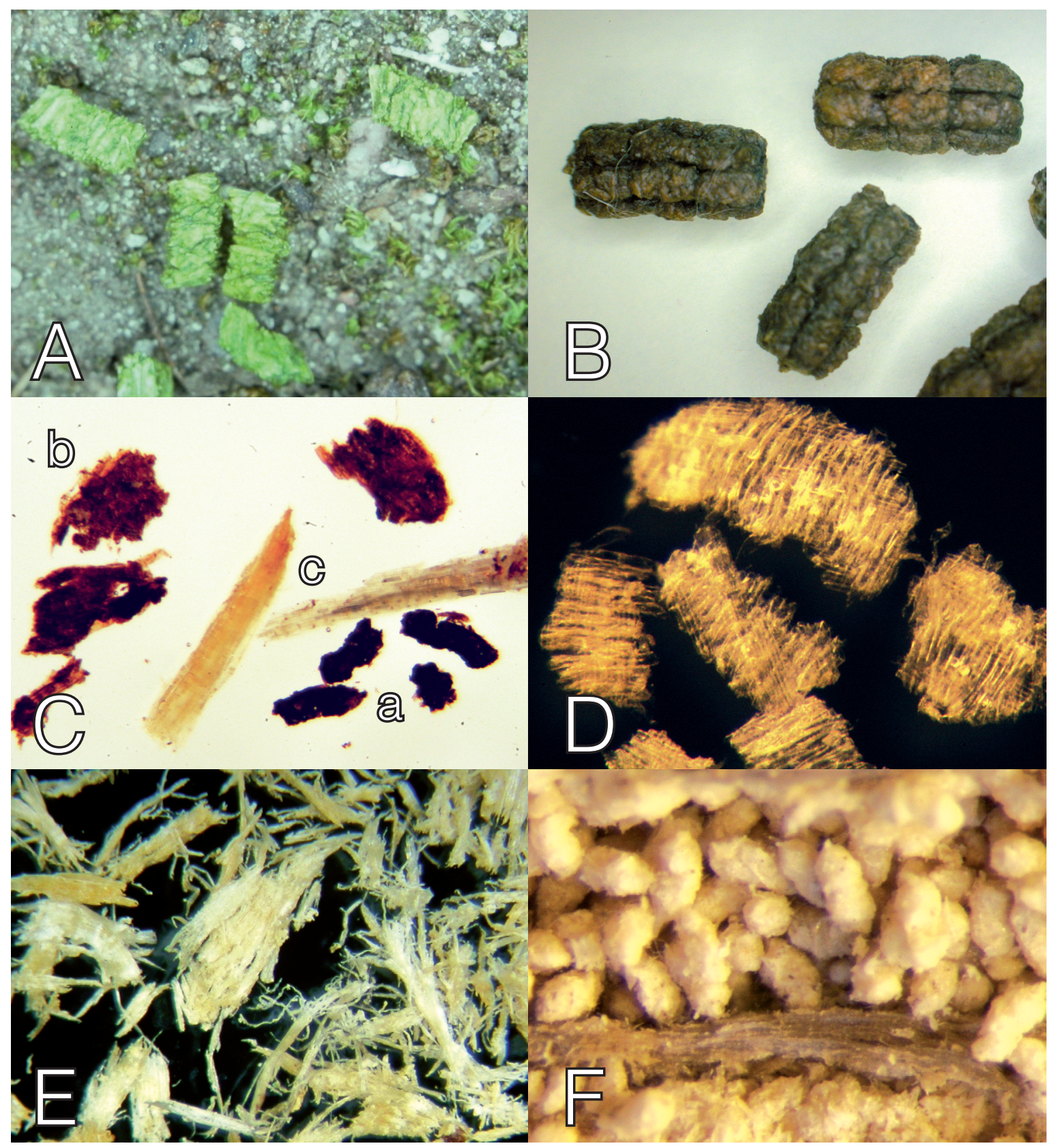

Plate I. Examples of frass and excrement produced by recent insects. The wood debris is sufficiently characteristic for use in insect determination. A. Excrement of the European pine sawfly (Neodiprion sertifer Geoffroy) that has dropped on the ground. Excrement size I.I x $3.0 \mathrm{~mm}$. B. Excrement of a larva of the pine hawk moth (Sphinx pinastri L.) are regularly grooved on their surface. Excrement length $3.8 \mathrm{~mm}$, but depends on the size of the larva. C. Frass produced by a larva of the timberman (Acanthocinus aedilis L.). $\mathrm{a}=$ excrement that has passed through the intestines, $b=$ frass loosened from phloem, $c=$ frass loosened from sapwood. The largest piece of excrement 1.5 $\mathrm{mm}$ in length. D. Wood chips loosened by young larva of the timber worm on conifers (Hylecoetus flabellicornis Schneider). They were found in the stump of a spruce. Diameter of the largest piece is $1.8 \mathrm{~mm}$. E. Wood fragments loosened by an adult carpenter ant (Camponotus herculeaneus L.) from the living trunk of a fir tree. Length on average $2.1 \mathrm{~mm}$. F. Frass of a powderpost beetle (Anobius sp.) from a gallery in a wooden wall beam. Frass length 0.4 mm. All photos: M.N. 
oured, and may be relatively long. Likewise the wood particles detached for the capsule are commonly long. Frass loosened from trees by larva of beetles are commonly sharp edged. The frass particles of phloem are brownish in colour. (Plate 1, C, frass of Acanthocinus larvae).

The excrement of wood-eating beetles is darker than the other wood material (Vité 1952, 1953). The excrement of long-horned beetles (Cerambycidae) is commonly cylindrical, but in e.g. Leptura rubra they are spherical and regular (Becker, 1949). Similarly, the excrement of adult larvae of the Pissodes (Curculionidae) genus are roundish, but the excrement of younger larvae are longish with an irregular shape (Fig. 4). The excrement of beetles that eat dead wood, example.g. Anobiidae beetles, are egg-like and smooth (Plate 1, F). Their shape resembles that of termite excrement (Weidner, 1956). In Anobiidae and termites, microbes play a significant role in the digestion process.

Ants, which carve their nests in wood, do not eat the wood material. Thus, the wood debris detached from living trees by Camponotus heculeaneus has rough outlines (Plate 1, E).

Needle-eating species commonly produce greenish excrement. Generally the colour depends on the material eaten (Nuorteva, 1972). The frass of adult Tomicus piniperda L. is multicoloured, and that of Trypodendron lineatum Ol. whitish. It may be possible to differentiate these bark beetles from other beetles living on pines, because their frass is reddish brown.

It is possible to identify the species of modern beetles living the under bark on the basis of the galleries they excavate. However, larger pieces of amber that contain galleries in bark have not been found in Baltic amber. As a result, there are no pieces of amber containing gallery networks available for insect identification. Only Krzemińska \& Krzemiński (1992) have published a photo of the gallery gnawed out by bark beetles (Scolytidae).

It should be noted that the excrement of other invertebrates might be similar to that of insects. Thus, centipedes (Chilopoda), millipedes (Diplopoda),

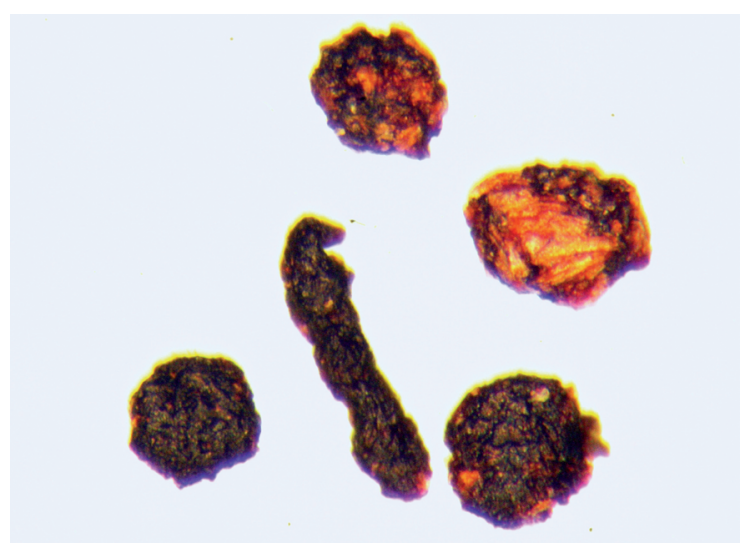

Fig. 4. Excrement of a modern adult Pissodes harcyniae (Hbst.) larva. The roundish pieces of excrement are frequently surrounded by a blackish film. Diameter of the largest piece is $0.5 \mathrm{~mm}$. One example of this genus, $P$. hennigsen Vosse, has been identified in Baltic amber (Voss 1972). Photo: M.N.

sow bugs (Isopoda), sea shells (Gastropoda) and spiders (Arachnoidea) should also be taken into account when identifying waste products.

\section{Examples of frass particles found in amber}

Our material of insect fossils in Baltic amber remained relatively limited, even though we studied a large number of amber fragments under the stereomicroscope. Therefore, in the following we describe only individual specimens of insect waste products, together with suggestions about the parent insect. Our comparison with the waste products of recent insects is mainly based on North European species, because we did not have any samples from more southerly ones.

The sphere in Figure 6 is similar to the excrement sphere of a beetle. A film coats the excrement. Under the coating one can see frass fragments composed of wood material. It resembles the roundish excrement produced by modern South European Anoplodera (Leptura) rubra L. (Becker 1949). In its larval stage this beetle caverns galleries in pine and rarely in oak tree (Ehnström \& Axelsson, 2002). Some species of 


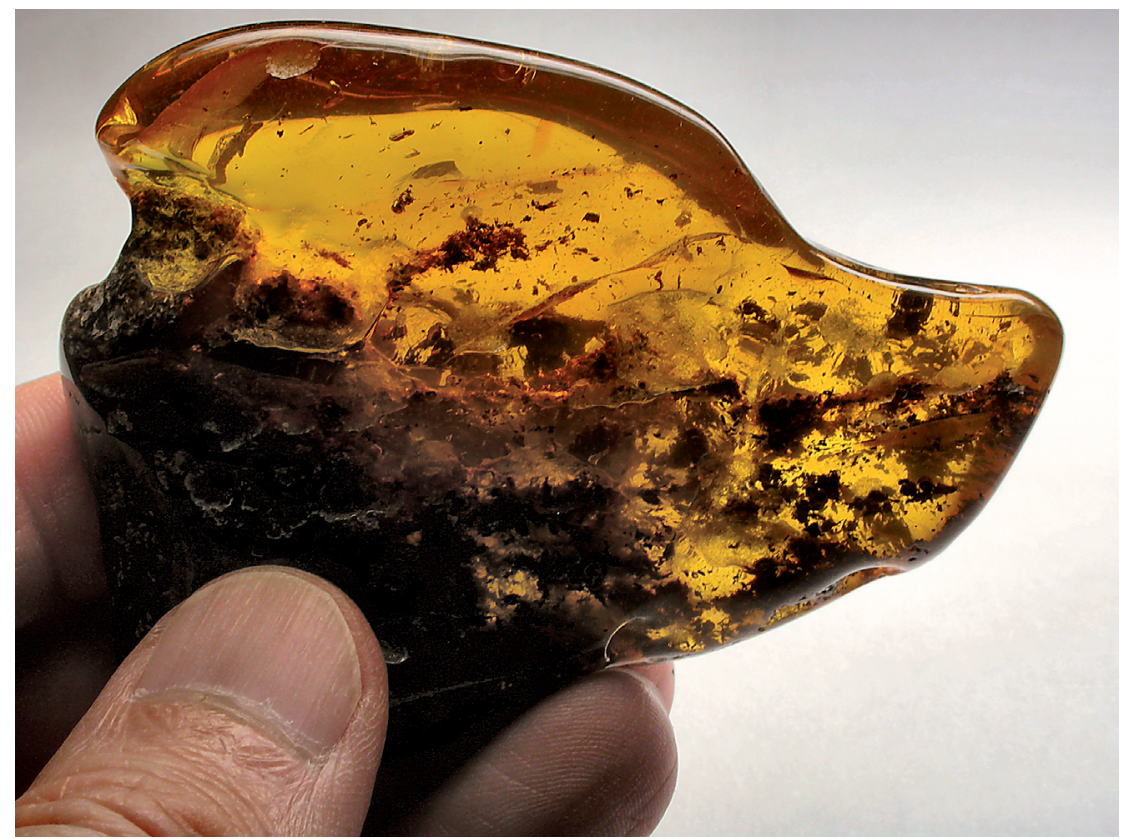

Fig. 5. This amber specimen is most probably from the Gdansk area, Poland. It is in the author's (K.K.) private collection. The amber specimen is $77 \times 58 \times 18 \mathrm{~mm}$ in size, transparent, clearly layered, containing thick layers $(1-12 \mathrm{~mm})$ of wood debris and five insect fossils. The excremental sphere is in the dark layer of wood debris. Photo: K.K.

Lepturinae have been met in Baltic amber (Larsson, 1978; Spahr, 1981). This amber specimen is shown in Figure 5.

The wood splinters depicted in Figure 7 were found in the same amber specimen (Fig. 5) as depicted in Figure 6. Their shape and light colour shows that they are frass carved by a beetle larva from the wood material, but have not passed through the insect's intestine. The shape of the beetle jaws gives the wood splinter a sharp-edged and sometimes parallelogrammic outline (cf. Plate 1).

In Figure 8 there is plenty of frass-resembling excrement (Fig. 8, B) close to a beetle of the Mordellidae family (Fig. 8, A). The size variation suggests that a larva of this beetle may have produced the frass. In this case they are not excrement, but pyrite, which is a common fracture filling material in Baltic amber. The number of species of beetle belonging to the Mordellidae family is small, but the number of individuals may be great (Ander, 1942). The modern species of this family live as larvae in the wood material decomposed by fungi of both broadleaf and coniferous trees (Larsson, 1978). This amber specimen in Figure 8 is from the Zoological Museum.

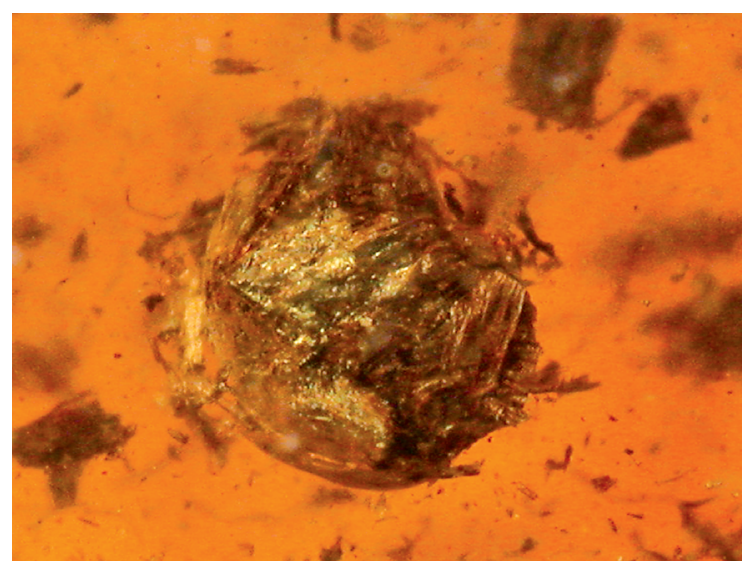

Fig. 6. An excremental sphere (diameter $1.6 \mathrm{~mm}$ ) composed of wood material. Photo: K.K.

The larvae of bag worms (Psychidae) gather sticks and other fragments in their cases (Fig. 9). Because many larvae also crawl along tree trunks, it is possible that they have used some frass loosened by other insects in constructing their capsule. Photos of cover capsules in amber can be found in Bachofen-Echt (1949), Weitschat \& Wichard (1998) and Grimaldi \& Engel (2005). Our photo is from amber sample 


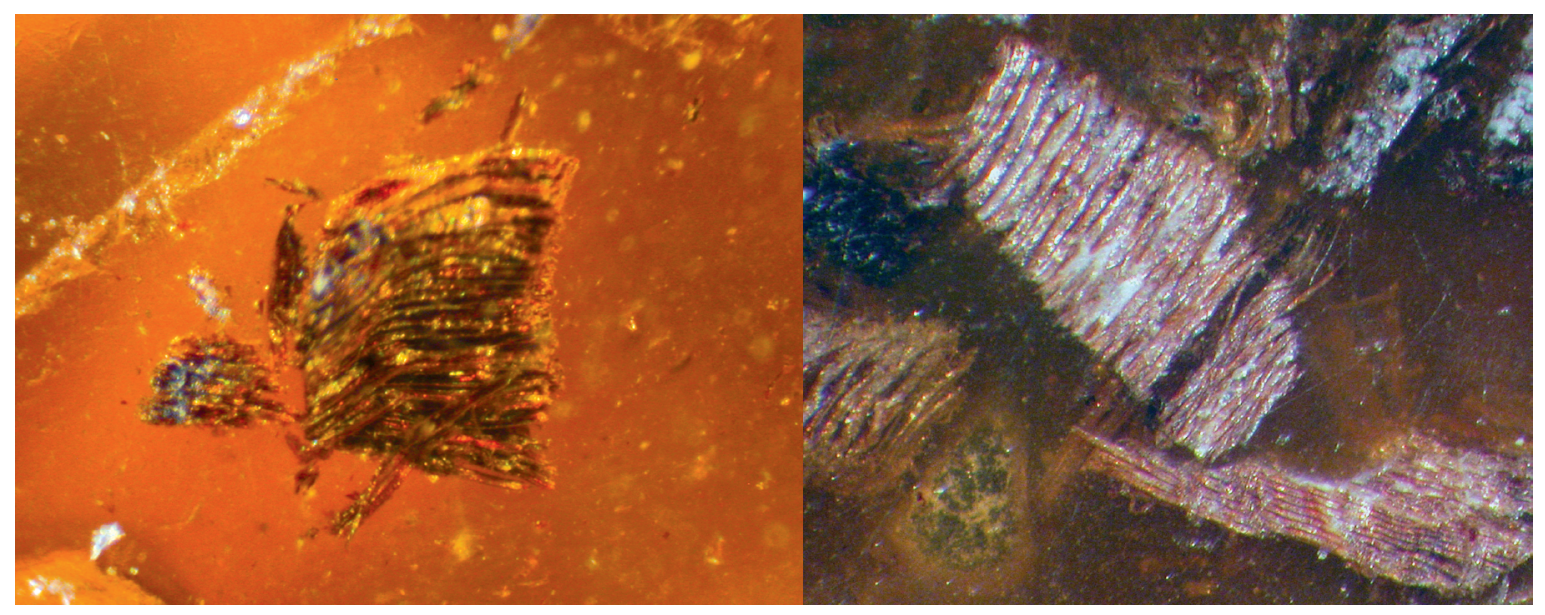

Fig. 7. Frass as parallelogram-shaped wood splinters (diameter I.0-1.5 mm). Amber specimen shown in Fig. 5. Photos: K.K.

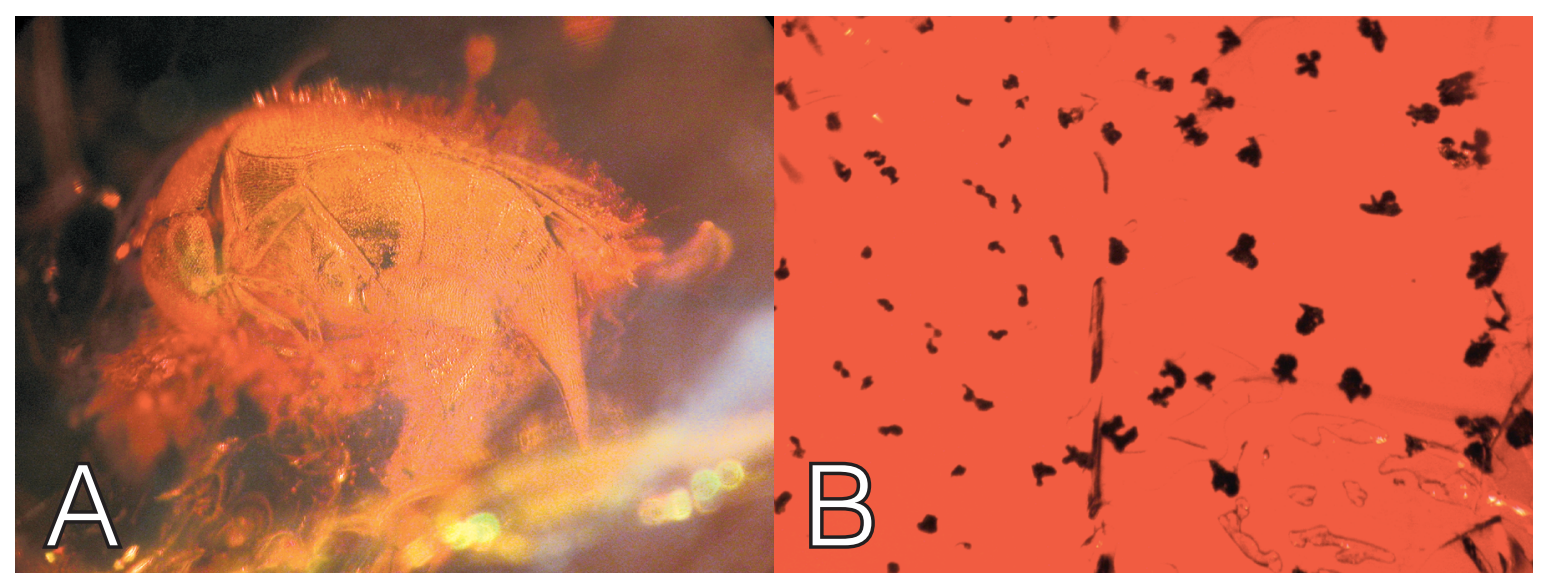

Fig. 8. (A) An adult beetle (length $3.0 \mathrm{~mm}$ ) alongside (B) pyrite crystals $(0.1-0.2 \mathrm{~mm})$ resembling the frass of a larva. Photo: K.K.

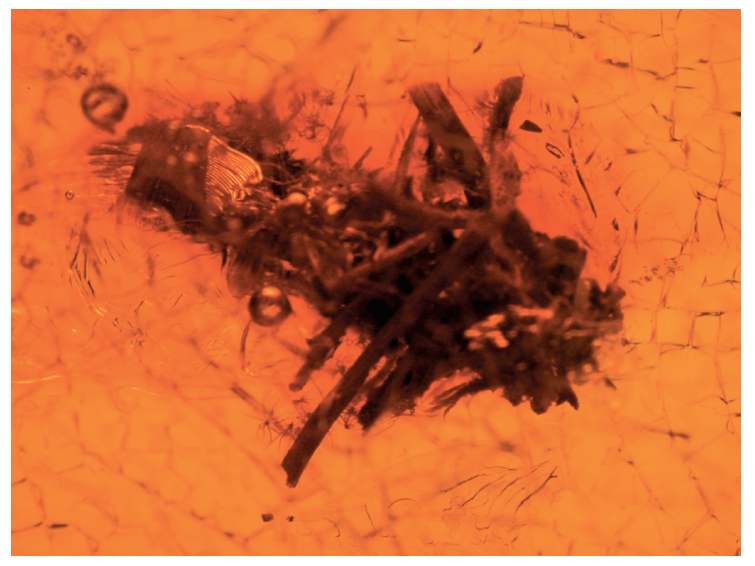

Fig. 9. Larval case (length $7.0 \mathrm{~mm}$ ) of a bagworm. Photo: K.K.

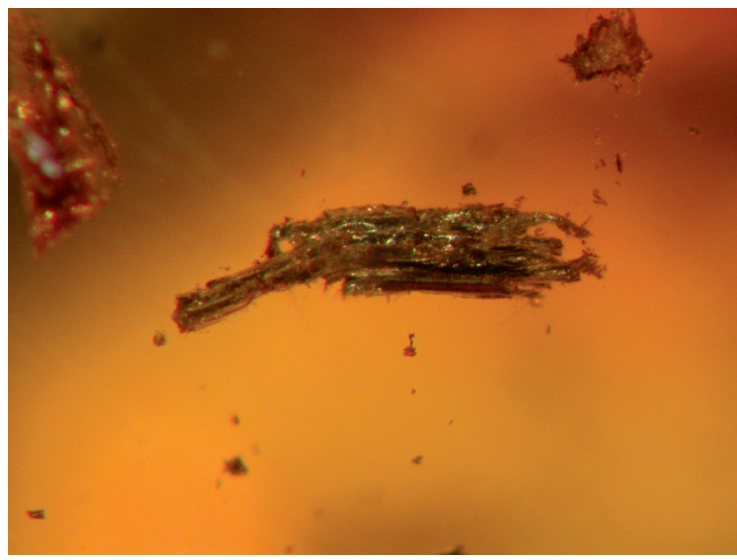

Fig. 10. Wood splinter (length $1.4 \mathrm{~mm}$ ) resembling the frass of a carpenter ant. Photo: K.K. 


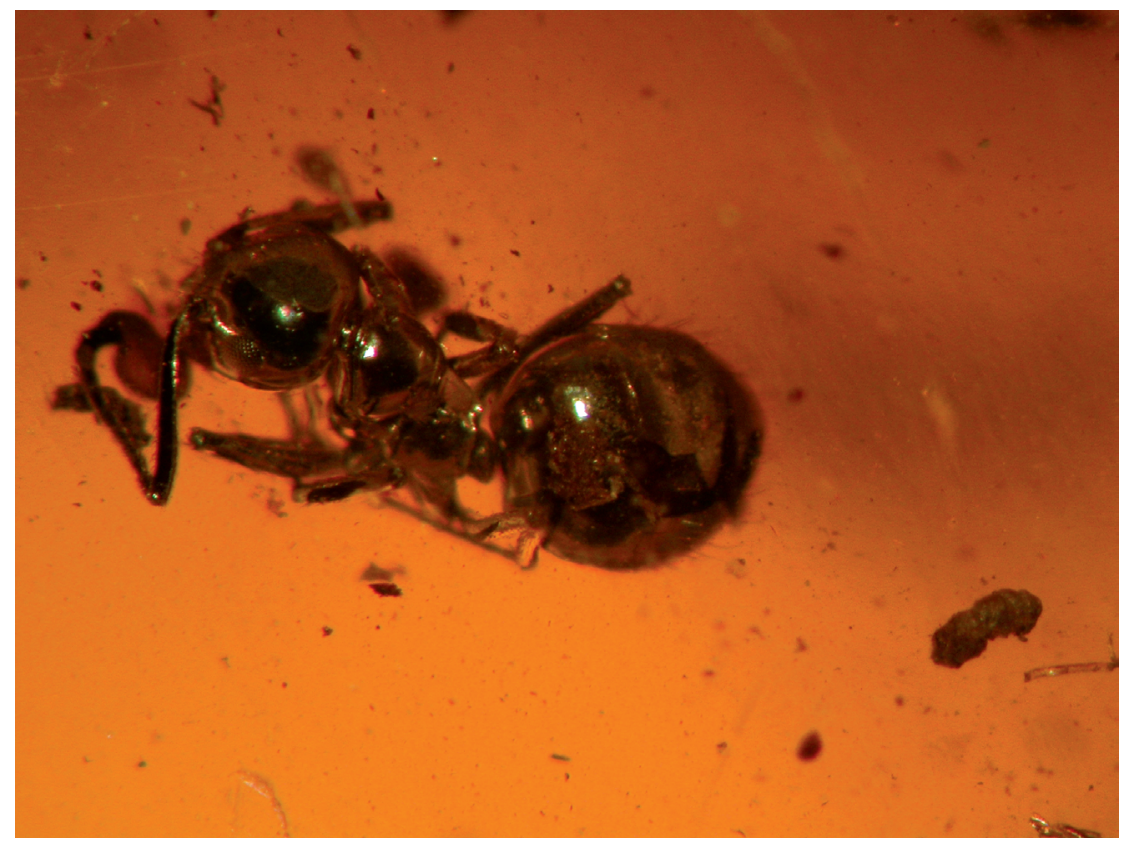

Fig. I I. Ant (length $2.3 \mathrm{~mm}$ ) and a piece of excrement in the right corner (length 0.5 $\mathrm{mm})$. Photo: K.K.

5640, Geological Museum, and its origin is Kaliningrad, Samland.

The fluffy wood particle in Figure 10 matches the frass that an insect has carved from the wood material. Its size and shape resembles the frass produced by carpenter ants, but a beetle may also have produced it. This amber was found in a bead in a Baltic amber bracelet in the private collection of K.K.

Many insects may defecate or even still lay eggs after they have become adhered to resin, and this could aid in their identification. However, the fecal pellet in the Figure 11 could also be derived from another insect and may merely have been carried by the ant. This amber specimen (the same as in Figures 6 and 7) is apparently from the Gdansk area, Poland, and it is in the other author's (K.K.) private collection. The ant and the pellet are located in its transparent layer without any wood debris.

The piece of excrement in Figure 12 closely resembles (see Nolte, 1939; Escherich, 1931) that produced by the larva of the pine beauty moth (Panolis flammea Schiff.). Similar pieces of excrement, but of different size, were found in a few other amber specimens. The pine beauty moth is currently a harmful pest of pines. This amber specimen (P5636) is from the collections of Geological Museum.

The inclusion droplet in Figure 13 may represent the honey-dew of an aphid. It has not become filled with water because it has irregular, cracked walls. One could verify the contents by determining the presence of sugar by chemical analysis. It is impossible to determine it taxonomically more exactly only on the basis of its morphology. This piece of amber was found from in a bead in a Baltic amber bracelet in the private collection of K.K.

As spiders live on trees in large numbers, they are common fossils in amber. Sometimes one can see fecal pellets and the residues of their animal victims as tiny bundles in the immediate vicinity of the spiders (Fig. 14). The shape of these bundles is spherical but ragged. However, we did not analyze these remains in sufficient detail because spiders do not belong to insects and were not included in the study. Figure 14 is from amber specimen number P 5638 (Geological Museum), the adult spider in which probably belongs to the Agelenidae family (det. by T. Pajunen, Zoological Museum), and originates from Kaliningrad, Samland. 


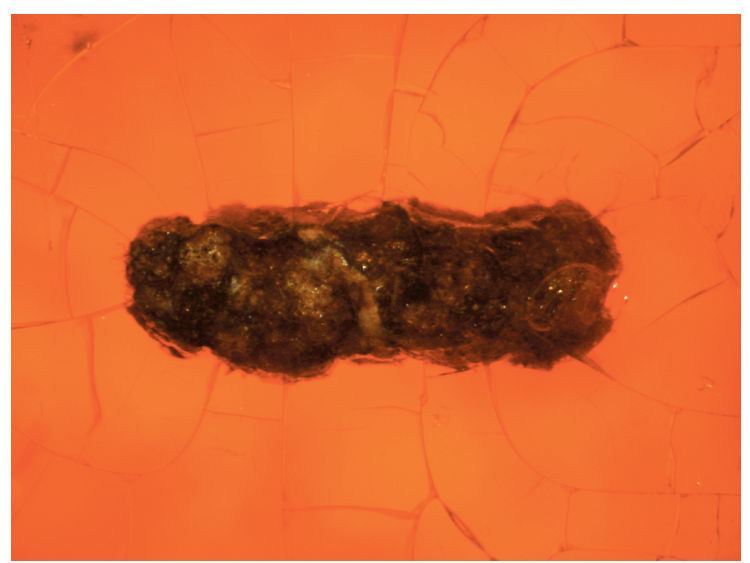

Fig. I 2.An elongated piece of excrement (dimensions 3.0 x $0.9 \mathrm{~mm}$ ) of a needle-eating larva. Photo: K.K.

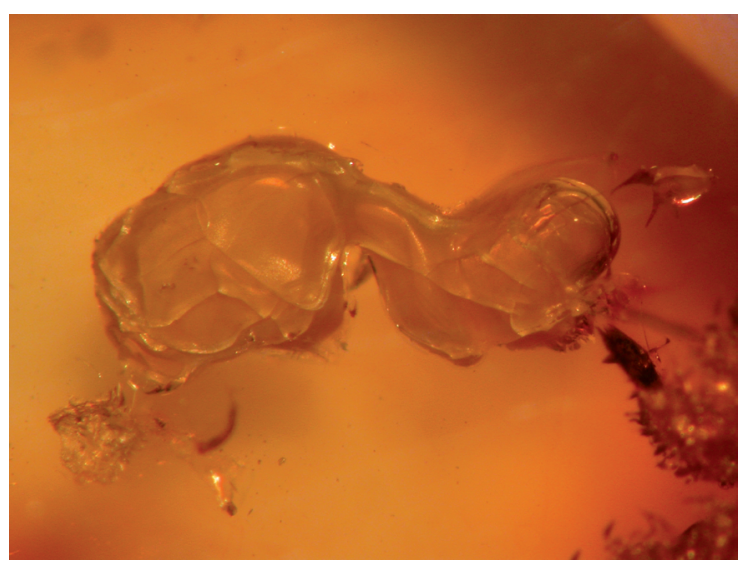

Fig. I 3. Possible honey-dew droplets (length $2.8 \mathrm{~mm}$ ) excreted by an aphid. Photo: K.K.

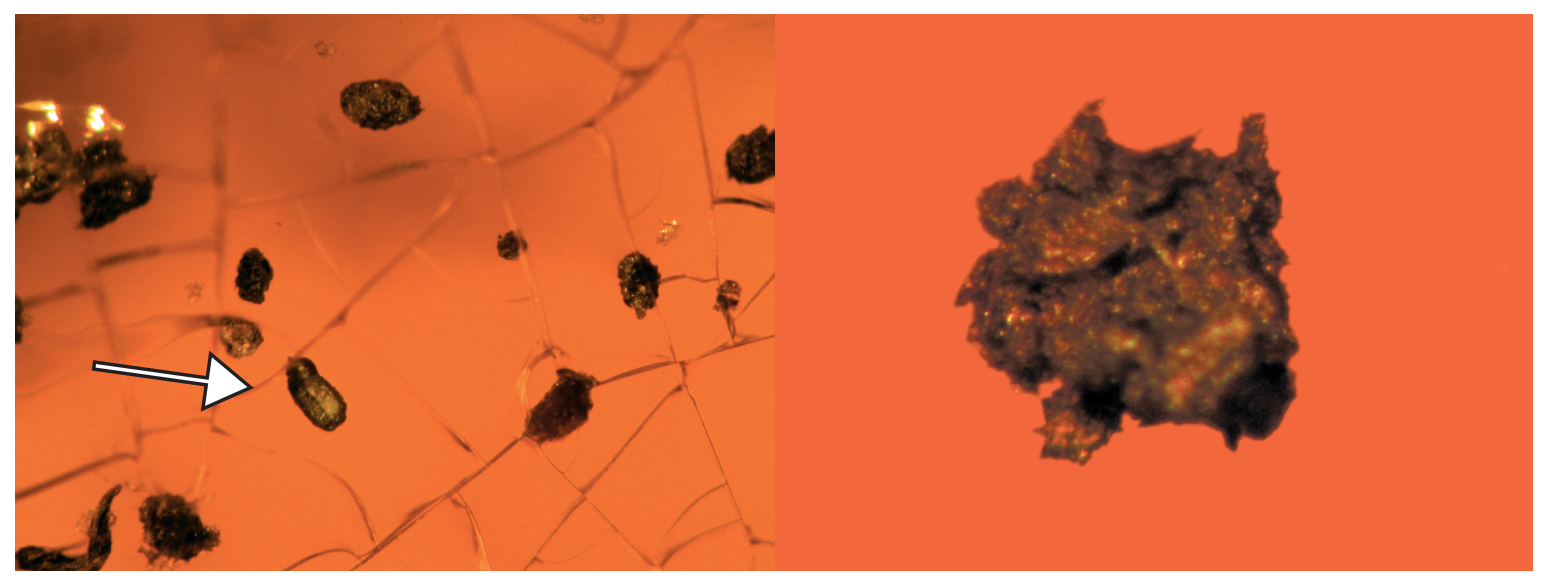

Fig. 14. Frass (arrow, an excrement?) of spiders (length $0.3-0.4 \mathrm{~mm}$ ). The photo in right is an enlargement of one large $(0.5 \mathrm{~mm})$ excrement (?) showing dissected remains of preys. Photo: K.K.

\section{Discussion}

The frass and excrement of many insects are sufficiently specific for their families or genera to be inferred. So far, however, the identification of frass and excrement does not meet the taxonomic requirements. In the future, more precise determinations may answer the question of whether the host trees were pines representing a number of species, or whether other conifers were also present. If we could obtain more evidence from insects not preserved in amber by studying their frass remains in amber, this would increase our knowledge of the earlier biocenosis. We empha- size that the potential of wood frass and excrement seems to be high in the identification of such insects.

Knowledge of the living habits of insects may aid their identification. For example, the excrement of larvae that eat needles may occur individually in amber, but the excrement of those living in wood may be among the frass.

Excrement size may indicate the former presence of large (over $1 \mathrm{~cm}$ ) insect species, although the insects have not been encapsulated in the resin. Accordingly, the excrement (Anoplodera?) found in amber (figure 6) is $1.6 \mathrm{~mm}$ in diameter, although modern adult larva of Pissodes harcyniae produces excrement 
that is $0.5 \mathrm{~mm}$ in diameter (figure 4). According to Ehnström \& Axelsson (2002), the size of adult Anoplodera rubra is $18 \mathrm{~mm}$ and that of Pissodes harcyniae $6 \mathrm{~mm}$. On the basis of the size of adults, the size of the larva that produced the excrement in figure 6 should be over $1 \mathrm{~cm}$. Therefore, large excrements indicate large species.

Although the waste products are diverse in origin, shape and size, they can potentially be used in insect identification in the following cases especially. If there are several frass particles in one piece of amber, it may simplify the identification. Likewise, the occurrence of adult insects and their parasites or predators in the same piece of amber may aid the identification of frass producers. Sometimes an insect trapped in amber may defecate during its death struggle (Müller, 1992; Arillo, 2007). If the excrement is still near the insect remains, then this too would aid in identification.

Although the amber forests evidently grew partly in the area of present Finland, the action of rivers and glaciers have transported the pieces of amber out of this area. Because, according to the fossil data, amber forests may have been located in mountainous country, it is possible that destruction of the forests may have resulted in serious erosion. This would have intensified the transportation of amber fragments towards the sea. Mountainous terrain would undoubtedly have caused large, local differences in the growing environment of the forest. The fauna, which was associated with the life span of the pines, seems to resemble primarily the species living in the Holarctic area. However, the relief in the paleogene and neogene region of present Finland is almost unknown. It is believed that weathering created valleys in the deeply weathered, fracture zones of the bedrock. The existence of mountaineous terrain seems, however, to be very unlikely.

Because many of the recent near relatives of the insects found in Baltic amber have a worldwide distribution, good knowledge and worldwide experience of insect groups are required. It would be too simple to assume that the climate in the amber pine forests was similar to that in the areas where the nearrelatives of the amber insects live today. Continen- tal drift, connected to plate tectonic movements, may have caused great changes in local environmental conditions. Likewise, the impact of repeated glaciation on taxonomic groups has varied locally. One example of this is the small number of tree species in present Europe compared to the numerous species in North America.

Most of the insects that adhered to the amber resin did not belong to the actual insect fauna of pine-like amber trees. Instead, the insects living in the pine-like trees produced frass. Large (over $1 \mathrm{~cm}$ ) insects did not become adhered to resin, although they would have formed a substantial part of the insect fauna living in dying trees. The frass that was produced by insects living in wood material and under the bark usually remained in holes. Knowledge of the living habits of insects suggests which species may have pushed out frass from under the bark. Sometimes piles of frass may have stuck to the resin, as the frass piles of modern termites imply.

The living habits of present bark beetles are very well known. The presence of different species would give fairly accurate information about the past environment. More finds of this insect group should be gathered and old records should be restudied. Some family names may at present refer to different species, and synonyms provide additional complication.

Schedl $(1947,1967)$ studied the bark beetles found in amber. These beetles include the still living genera Hylastes and Hylurgops, as well as four extinct genera. However, the species belonging to the families Orthotomicus, Ips, Pityophthorus and Pityogenes, which are common in present pines, were not found (Larsson, 1978; Bachofen-Echt, 1996; Zherikhin, 2002). We suggest that one explanation for the absence of individuals of these insect families could be adaptation and learned behaviour to avoid resinous traps. It is likewise possible that bark beetles were not associated with the death of the already weakened trees. Bark beetles as small animals may also have been overlooked when pieces of raw amber were selected for specimens containing insects (Larsson,1978). Hylurgops and Hylastes species often attack the damp and somewhat decayed inner bark of the lower trunk of 
trees. Typical localities are the bases of trees broken by storms. Broken trees still possess considerable vitality, and there is still a high possibility of resin flows catching the beetles under the bark. Perhaps this explains why beetles of these two families have, in particular, been found in Baltic amber.

Although spiders are not insects, sensu stricto, it is possible that their excrement is also present and they should be included in future studies. One example of their frass is shown in Figure 14. It seems possible to identify this frass material, because it consists of shining chitin chips. Spiders are common on tree trunks and in the canopies and many of them were trapped in amber. Spiders suck fluids from their insect prey and crush the hard parts with their jaws. These residues are common near spider adults encapsulated in amber. Because our expertise is insufficient for their identification, we have not discussed them further. Wunderlich (2002) has published his extensive studies on spiders in amber.

The strength of resin to trap insects and parts of plants depended largely on its viscosity. The composition of the fossil record may thus reflect the time of the day or season at the trapping moment. Accordingly, needles of pine-like trees are remarkably rare in Baltic amber (Bachofen-Echt, 1949; Schlee, 1990; Weitschat \& Wichard, 1998; Krzemińska \& Krzemiński, 1992). In the other author’s (K.K.) collection there is one sample where there is a distinctly shaped cavity in the place of a decayed needle of some pine-like tree. Modern pines drop their 3- to 4-yearold needles each year. Needles are relatively large and are mainly shed in autumn and winter. At that time of the year the surface of resin had already hardened. In springtime, the resin was in a fluid form and at the tiny hairs shed from the oak leaves became easily trapped by the resin. This suggests that spring- and summertime similarly favoured the trapping of frass (cf. Ross, 1998).

\section{Conclusions}

This study demonstrates that insects produce (and have produced) diagnostic frass and excrement. How- ever, they have not been precisely studied nor classified (Zherikhin, 2003). Insects that eat wood material and needles produced frass very close to the resin produced by the host tree. The possible frass-producing species can be narrowed down to a few candidates through knowledge of the living habits of insects. A digital image collection should be compiled of frass and compared to the debris produced by recent insects.

At present, the literature on wood debris produced by modern insects is fragmental. We suggest that a comprehensive literary review on the frass and excrement of present-day insects should first be compiled. A similar study was published on the diagnostic microfossils observed in archaeological flint material in Finland (Kinnunen et al., 1985). In the same way, "Bugs" software has been compiled to aid archaeologist by providing ecological and distributional data on modern fauna in order to enable more precise reconstructions of past environments (Buckland et al., 1997). This kind of data catalogue should include data on insect breeding and direct observations from nature. An information system on frass and excrement produced by modern insects would help in reconstructing former environments and the roles played by insects in ecosystems.

The suggested image catalogue should describe the morphology, size, structure and other diagnostic features of frass and excrement. It is known that the debris of adult insects remains constant, but that of larvae increase as they grow. Therefore, the debris (excrement, frass and flakes formed during capsulation) should include that of both adults and larvae. Determination of individual frass particles may remain difficult owing to their varied shape.

This indirect method does not yet enable accurate identification of species. However, if the reference material is large enough, identifications may become more exact. It could indicate the existence of species which were not trapped in amber because of their large size or living habits. Furthermore, the adults of parasitic and predatory insects in amber may imply the presence of their host animals. 


\section{Acknowledgements}

We thank intendent Anneli Uutela from the Geological Museum and intendent Larry Hulden from the Zoological Museum, both of the Finnish Museum of Natural History, for kindly lending us museum material for this study. The manuscript was refereed by Professor George Poinar Jr. from the Oregon State University, which is highly appreciated. We likewise thank librarian Leena Tulisalo of Helsinki University and the competent staff in the library of The Geological Survey of Finland for acquiring the difficult to find literature material for our study. In addition, we thank museum caretaker Timo Pajunen from the Zoological Museum for identifying one araneidan fossil. Similarly, we thank Dr. John Derome for checking the English language of the manuscript.

\section{References}

Ander, K., 1942. Die Insektenfauna des baltischen Bernsteins nebst damit verknüpften zoogeographischen Problemen. - Lunds Universitets Årsskrift. N.F. Avd. 2. Bd $38 \mathrm{Nr}$ 4, $83 \mathrm{p}$.

Arillo, A., 2007. Paleoethology: fossilized behaviors in amber. Geologica Acta 5 (2), 159-166.

Äyräpää, A., 1945. Die Verbreitung des Bernsteins in kammkeramischen Gebiet. Suomen Muinaismuistoyhdistyksen Aikakauskirja XLV, 10-25.

Äyräpää, A., 1960. Neue Beiträge zur Verbreitung des Bernsteins in kammkeramischen Gebiet. Swiatowit XXIII, $235-247$.

Bachofen-Echt, A., 1949. Der Bernstein und seine Einschlüsse. 1996, Nachdruck der Auflage von 1949. Jörg Wunderlich Verlag, 230 p.

Beck, C.W., 1993. Der Wissensstand über chemische Struktur und botanische Herkunft des Bernsteins. Miscellanea Archaeologica Thaddaeo Malinowski Dedicata, 1993, 27-38.

Becker, G., 1949. Bestimmung von Insektenfrasschäden an Nadelholz. Zeitschrift für angewandte Entomologie 31, 275-303.

Botheroyd, S. \& Botheroyd, P.F., 2004. Das Bernstein-Buch. Atmosphären Verlag, München, 135 p.

Brauns, A., 1954. Terricole Dipterenlarven. Musterschmidt, Wissenschaflicher Verlag, Göttingen, 179 p. + 96 fig.

Buckland, P,I., Yan Zhuo D. \& Buckland, P.C., 1997. Towards an expert system in Palaeoentomology. Quaternary Proceedings 5, John Wiley \& Sons, Chichester, 71-77.

Dahlström, A. \& Brost, L., 1995. Stenen som flyter och brinner. Norstedts Förlag, Helsingfors, 137 p.
Eckstein, K., 1939. Exkremente und Bohrmehl forstschädlicher Insekten. VII. Internationaler Kongress für Entomologie, Verhandlungen, Band III, 1930-1936, and 5 tabelle.

Ehnström, B. \& Axelsson, R., 2002. Insekts gnag i bark och ved. ArtDatabanken SLU, Uppsala, 512 p.

Escherich, K.. 1931. Die Forstinsekten Mitteleuropas, III Band, Verlag Paul Parey, Berlin, 825 p.

Escherich, K., 1942. Die Forstinsekten Mitteleuropas, V Band, Verlag Paul Parey, Berlin, 746 p.

Evenhuis, N.E., 1994. Catalogue of the fossil flies of the World (Insecta: Diptera). Backhuys Publishers, Leiden, 600 p.

Grimaldi, D.J.,1996. Amber. Window to the past. Abrams/ American Museum of Natural History, New York, $216 \mathrm{p}$.

Grimaldi, D. \& Engel, M.S., 2005. Evolution of the insects. Cambridge University Press, 755 p.

Grzonkowski, J., 2004. Bernstein. III Auflage, Ellert \& Richter Verlag, Hamburg, 133 p.

Grönhagen, J., 1991. An amber pendant from Astuvansal$\mathrm{mi}$ in Ristiina, Finland. Fennoscandia archaeologica VIII, 73-76.

Gübelin, E.J., 1978. The tears of Heliades. Gems \& Gemology 16, 66-77.

Heie, O.E., 1967. Studies on fossil Aphids (Homoptera: Aphidoidea). Spolia Zoologica Musei Hauniensis 26, 273 p.

Holmberg, H.J., 1857. Mineralogischer Wegweiser durch Finnland. Finska Vetenskapssocieten, Fösta Häftet, Helsinki, 76 p.

Katinas, V., 1983. Baltijos gintaras (Baltic amber). Vilnius, Mosklas, 112 p. (In Latvian, cited in Milkovsky, 1995).

Keilbach, R., 1982. Bibliographie und Liste der Arten tierischen Einschlüsse in fossilen Harzen sowie ihrer Aufbewahrungsorte. Deutsche Entomologische Zeitschrift, N.F. 29, 129-286.

Kinnunen, K., Tynni, R., Hokkanen, K. \& Taavitsainen, J-P., 1985. Flint raw materials of prehistoric Finland: rock types, surface textures and microfossils. Geological Survey of Finland, Bulletin 334, 59 p. +40 plates.

Kohonen, J. \& Rämö, O.T., 2005. Sedimentary rocks, diabases, and late cratonic evolution. In: Lehtinen, M., Nurmi, P. A. \& Rämö, O. T. (eds.) Precambrian geology of Finland - Key to the evolution of the Fennoscandian Shield. Developments in Precambrian Geology 14, 563-603.

Koponen, M. \& Nuorteva, M., 1973. Über subfossile Waldinsekten aus dem Moor Piilonsuo in Südfinnland. Acta Entomologica Fennica 29, 84 p.

Kosmowska-Ceranowicz, B., 2001. Wie Bernstein entsteht. In: Krumbiegel \& Krumbiegel (eds.) Faszination Bernstein, Goldschneck-Verlag, Weinstadt, pp. 17-35.

Kosmowska-Ceranowicz, B., 2004. Quaternary amber-bearing deposits on the Polish coast. Zeitschrift für angewandte Geologie, Sonderheft 2/2004, 73-84. 
Krzemińska, E. \& Krzemiński, W., 1992. Les fantomes de l'ambre. Musée d'histoir naturelle de Neuchâtel, Suisse, 142 p.

Krumbiegel, G. \& Krumbiegel, B., 2005. Bernstein. Fossile Harze aus aller Welt. III Aufl., - Goldschneck im Quelle \& Meyer Verlag GmbH \& Co., Wiebelsheim, 112 p.

Labandeira, C.C., LePage, B.E. \& Johnson, A.H., 2001. A Denroctomus bark engraving (Coloptera: Scolytidae) from a middle Eocene Larix (Coniferales: Pinaceae): early delayed or delayed colonization? American Journal of Botany 88 (11), 2026-2039.

Laitakari, A., 1967. Suomen mineraalien hakemisto. Index of Finnish minerals with bibliography. Bulletin de la Commission Géologique de Finlande 230, 842 p.

Larsson, S.G., 1978. Baltic amber - a palaeobiological study. Entomonograph, volume 1, 192 p.

Larsson, S. \& Tenow, O., 1980. Needle-eating insects and grazing dynamics in a mature scots pine forest in Central Sweden. In: Persson, T. (ed.) Structure and Function of Northern Coniferous Forests. An Ecosystem Study, Ecological Bulletins (Stockholm) 32, 269-303.

Mlíkovsky, J., 1995. Tertiary avian localities of Finland. In: Mlíkovsky, J. (ed.) Tertiary avian localities of Europe. Acta Universitatis Carolinae Geologica 39 (3-4), 563-565.

Müller, A.H., 1992. Lehrbuch der Paläozoologie. Band I. Allgemeine Grundlagen. 5. Auflage, Gustav Fischer Verlag, $514 \mathrm{p}$.

Nolte, H.-W., 1939. Über den Kot von Fichten- und Kieferninsekten. Tharandter Forstliches Jahrbuch 90, 740-761.

Nuorteva, M., 1956. Über den Fichtenstamm-Bastkäfer, Hylurgops palliatus Gyll., und seine Insektenfeinde. Acta Entomologica Fennica 13, 118 p.

Nuorteva, M., 1972. Die Geschwindigkeit der Nahrungspassage durch den Darmkanal bei Hylobius abietis L. Imagines (Col., Curculionidae). Annales Entomologici Fennici 38, 113-118.

Overeem, I., Weltje, G. J., C. Bishop-Kay, C. \& Kroonenberg, S.B., 2001. The Late Cenozoic Eridanos delta system in the Southern North Sea Basin: a climate signal in sediment supply? Basin Research 13, 293-312.

Pieińska, A., 2001. Pflanzen im Bernstein. In: Krumbiegel \& Krumbiegel (eds.) Faszination Bernstein, Goldschneck-Verlag, Weinstadt, $111 \mathrm{p}$.

Poinar, G.O. Jr. 1992. Life in amber. Standfor University Press, Standfor, California, 350 p.

Reinicke, R., 1995. Bernstein, Gold des Meeres. III Auflage, Hinstroff Verlag, Rostock, 80 p.

Ross, A., 1998. Amber. The Natural Time Capsule. Natural History Museum, London, 73 p.

Schedl, K.E., 1947. Die Borkenkäfer des baltischen Bernsteins. Zentralblatt für das Gesamtgebiet der Entomologie 2, 12-48.

Schedl, K.E., 1967. Bernsteinborkenkäfer aus dem Zoologischen Museum der Universität Kopenhagen. Entomologiske Meddelelser 35, 85-87.
Schlee, D., 1990. Das Bernstein-Kabinett. Stuttgarter Beiträge zur Naturkunde. Serie C, Nr. 28, 100 p.

Schubert, K., 1939. Mikroskopische Untersuchungen pflanzlicher Einschlüsse des Bernsteins. I Holz. Bernsteinforschungen 4, p. 23-44.

Selden, P. \& Nudds, J., 2004. Evolution of fossil ecosystems. Manson Publishing, London, 160 p.

Shashoua, Y., 2002. Degradation and inhibitive conservation of Baltic amber in museum collections. Department of Conservation. The National Museum of Denmark, $40 \mathrm{p}$.

Spahr, U., 1981. Systematischer Katalog der Bernstein- und Kopal-Käfer (Coleoptera). Stuttgarter Beiträge Naturkunde, Ser. B. 80, 107 p.

Szadziewski, R. \& Sontag, E., 2001. Tiere im Bernstein. In: Krumbiegel \& Krumbiegel (eds.) Faszination Bernstein, Goldschneck-Verlag, Weinstadt, pp. 51-71.

Uino, P., 2005. Bärnstenssmycken, föremål av lera samt kåda. Finskt Museum 2002, 109, 80-83.

Vité, J.P., 1952. Die holzzerstörenden Insekten Mitteleuropas. Textband 1952, Musterschmidt wissenschaftlicher Verlag, Göttingen, 155 p.

Vité, J.P., 1953. Die holzzerstörenden Insekten Mitteleuropas. Tafelband 1953, Musterschmidt wissenschaftlicher Verlag, Göttingen, 78 p.

Voss, E., 1972. Einige Rüsselkäfer der Tertiärzeit aus Baltischem Bernstein (Coleoptera, Curculionidae). Steenstrupia, Zoological Museum, University of Copenhagen 2, 167-181.

Weidner, H., 1956. Kotballen von Termiten im Bernstein. Veröffentlichungen aus dem Überseemuseum in Bremen 2 A., 363-364.

Weitschat, W. \& Wichard, W., 1998. Atlas der Pflanzen und Tiere in Baltischen Bernstein. - Verrlag Friedrich Pfeil, München, 256 p.

Wichard, W. \& Weitschat, W., 1996. Wasserinsekten im Bernstein. Entomologische Mitteilungen aus dem Löbbecke-Museum und Aquazoo 4, $121 \mathrm{p}$.

Wichard, W. \& Weitschat, W., 2005. Im Bernsteinwald. 2. Auflage. Gerstenberg Verlag, Hildesheim, 168 p.

Wunderlich, J., 1986. Spinnenfauna gestern und heute. Erich Bauer Verlag bei Quelle \& Meyer, Wiesbaden, 283 p.

Wunderlich, J., 2004. Fossil spiders in amber and copal. Beiträge zur Araneologi, 3 A and B.Verlag Jörg Wunderlich, Hirschberg-Leutershausen, Germany, 1908 p.

Zherikhin, V.V., 2002. Ecological history of terrestrial insects. In: Rasnitsyn, A.P. \& Quicke (eds.) History of insects, Kluwer Academic Publishers, pp. 331-388.

Zherikhin, V.V., 2003. Insect trace fossils, their diversity, classification and scientific importance. Acta zoological cracoviensia 46 (supplement), 59-66. 